\title{
Protozoan parasites of Xiphophorus spp. (Poeciliidae) and their relation with water characteristics
}

\author{
[Parasitos protozoários de Xiphophorus sp. (Poeciliidae) e a relação deles com as características da água]

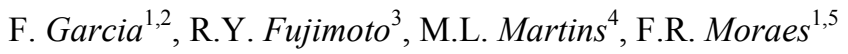 \\ ${ }^{1}$ Centro de Aquicultura - UNESP - Jaboticabal, SP \\ ${ }^{2}$ Pólo Regional do Noroeste Paulista - APTA \\ Caixa Postal 61 \\ 15500-000 - Votuporanga, SP \\ ${ }^{3}$ Universidade Federal do Pará - Bragança, PA \\ ${ }^{4}$ Departamento de Aquicultura - UFSC - Florianópolis, SC \\ ${ }^{5}$ Faculdade de Ciências Agrárias e Veterinárias - UNESP - Jaboticabal, SP
}

\begin{abstract}
This work investigated the relationship between water characteristics and infestation of protozoan parasites, Icthyophthirius multifiliis and Trichodina sp., in swordtails (Xiphophorus helleri) and platy (Xiphophorus maculates) collected in an ornamental fish farm in São Paulo, Brazil. Fish were monthly collected from ponds and tanks for one year. The prevalence rates in fish from tanks and ponds were, respectively, $34.2 \%$ and $22.5 \%$ for I. multifiliis, and $13 \%$ and $54.2 \%$ for Trichodina $\mathrm{sp}$. Increased electric conductivity and $\mathrm{pH}$ provoked reduction of I. multifiliis infestation. Low oxygen concentration increased Trichodina sp. infestation. The use of salt to increase the electric conductivity of water was a method to control I. multifiliis. Low dissolved oxygen and the addition of organic fertilizer favored the reproduction of Trichodina sp.
\end{abstract}

Keywords: swordtails, platy, parasite, protozoan, Trichodina sp., Icthyophthirius multifiliis

\section{RESUMO}

Investigou-se a relação entre as características da água e a infestação de protozoários parasitos, Icthyophthirius multifiliis e Trichodina $s p$., em peixe espada, Xiphophorus helleri e em plati, Xiphophorus maculatus, coletados em uma piscicultura de peixes ornamentais no Estado de São Paulo, Brasil. Os peixes foram coletados mensalmente, durante um ano, dos viveiros e das caixas de estocagem. A prevalência da infestação nos peixes das caixas e dos viveiros foram, respectivamente, $34,2 \%$ e 22,5\% para I. multifiliis e $13 \%$ e $54 \%$ para Trichodina sp. A elevada condutividade elétrica e o pH da água reduziram a infestação por I. multifiliis. A baixa concentração de oxigênio resultou em aumento na infestação por Trichodina sp. O uso do sal, para aumentar a condutividade elétrica da água, consistiu em um método de controle de I. multifiliis. A redução do oxigênio dissolvido e a adição de fertilizante orgânico favoreceram a reprodução de Trichodina sp.

Palavras-chave: peixe-espada, plati, parasito, protozoário, Trichodina sp., Icthyophthirius multifiliis

\section{INTRODUCTION}

Ornamental fish production is an important segment of pet animals industry. The annual revenue with aquarium and ornamental fish sales in the world is estimated in US\$ 900 million (Evans and Lester, 2001).

In Brazil, ornamental fish trade is incipient, but the market has a promise for the future. Lima et al. (2001) pointed out that Brazilian ornamental

Recebido em 26 de abril de 2007

Aceito em 15 de outubro de 2008

E-mail: fgarcia@apta.sp.gov.br 
fish industry has increased due global requirement. However, the technology of production is not very spread and there are not observations about sanitary aspects or disease occurrence in fish. Parasitology of cultivated fish is currently focussed on the agents that cause diseases, whereas little attention has been given on the native ornamental fish.

Fish farms provide ideal conditions for transmission of infectious diseases, particularly those involving macroparasites with direct life cycles (Buchmann et al., 1987; Hogans, 1989). To deal with such problems, the fish farm usually relies on chemical dips. Unfortunately, chemical treatment is often associated with side effects that include parasite resistance, host damage, and environmental pollution (Buchmann and Bjerragaard, 1990; Buchmann et al., 1992). An alternative approach is to manipulate the physical environment at farm such as temperature, salinity, $\mathrm{pH}$, and dissolved oxygen in such a way to minimize effective transmission of the parasite and thus minimize their impact. On this point of view, the relation between parasite occurrence and water characteristics is required.

Among the main commercialized fish, swordtail Xiphophorus helleri Heckel 1848 and platy Xiphophorus maculatus Günther 1866 are ornamental specimens of Poeciliidae family, viviparous, and considered prolific. They reproduce during the whole year by intern fecundation. Larvae are born with adult characteristics, but smaller. The ideal water temperature varies from 22 to $27^{\circ} \mathrm{C}$ and the ideal $\mathrm{pH}$ is 7.0 (Fernandez, 1981). Martins et al. (2007) described Camallanus maculatus n. sp. (Nematoda: Camallanidae) from Xiphophorus maculatus (Osteichthyes: Poecilidae) collected in an ornamental fish farm in São Paulo State, Brazil, with $82 \%$ of prevalence and mean intensity of 2.8. Garcia et al. (2003) showed high level of infection by monogenean parasite Urocleidoides sp. in all samples of Xiphophorus sp., reaching up to $100 \%$ of prevalence, which shows the susceptibility of this host.

In freshwater and marine aquaculture, protozoan parasites are more frequent with high prevalence rates of Icthyophthirius multifiliis Fouquet 1876 (Protozoa: Ciliophora, Ophryoglenidae) infection. Its reproduction is favored by climatec changes especially in temperate regions (Wooten, 1998). Almost ever, Xiphophorus sp. is infested by $I$. multifiliis, being more susceptible than Carassius auratus (Clayton and Price, 1987; 1992; 1994; Price et al., 1985; Ling et al., 1992; Ling et al., 1995).

In studies with $X$. maculatus $\mathrm{x} X$. variatus hybrid, Clayton and Price (1994) did not observe influence from the host gender or the water temperature upon parasitism by I. multifiliis. Nevertheless, the calculated heterosis for resistance to I. multifiis was $31.3 \%$. It confirms the existence of genetic factor which determines resistance and that may be reached by hybridization.

Trichodina sp. Ehrenberg 1830 (Protozoa: Ciliophora) is another protozoan parasite found on body surface of fish. There is little information about Trichodina infestation in ornamental fish. Studies suggest that prevalence rates vary from $7.7 \%$ to $87 \%$ in farmed fish (Ranzani-Paiva et al., 1998; Vargas et al., 2000; Tavares-Dias et al., 2001; Martins et al., 2002).

The present work investigated the relationship between dissolved oxygen, electric conductivity, $\mathrm{pH}$, water temperature, and protozoan infections in $X$. helleri and $X$. maculatus.

\section{MATERIAL AND METHODS}

Fish were collected in an ornamental fish farm in

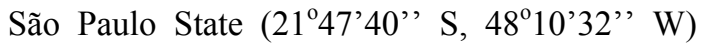
and transported to the Aquaculture Center, at the Universidade do Estado de São, Jaboticabal, SP, Brazil. The facility is characterized by a semiintensive system in earth ponds with $16.8 \mathrm{~m}^{3}$ capacity. These ponds are provided by mine and artesian water, in which the inlet water is inter communicable. Thus, the water passed from the first pond to the last from the surface.

Some fish species were raised together. Fish were caught by a hand hold net or during the complete emptying of the ponds. They were manually selected by separating each species and class of size in trays containing $1.0 \mathrm{~cm}$ water. After that, fish were maintained in $250 \mathrm{~L}$ tanks for 10 days, provided by constant flow of water and controlled temperature until the sale. 
Monthly, ten $X$. hellleri and/or $X$. maculatus lengthing $4.98 \pm 1.2 \mathrm{~cm}$ were collected from tanks and ponds for a period of one year for parasitological examination. In September and December, no water analysis were performed due to the interruption of the routine activities in the fish farm.

Water temperature, electric conductivity, $\mathrm{pH}$, and dissolved oxygen were monthly measured by YSI equipment, at the moment when fish were caught in each different stocking system.

After anaesthesia with benzocaine solution, fish were sacrificed and skin mucus was microscopically examined. The number of parasites was estimated in a scale that varied from zero to five, according to the number found in microscope by using $10 \mathrm{x}$ magnification. Specimens of trichodinids, obtained from scrapings from the skin, were air dried and impregnated with an aqueous solution of silver nitrate during eight minutes followed by one to two hours of exposure to UV light (Klein's dry silver impregnation technique) (Eiras et al., 2000). Prevalence ([number of infected host/number of examined host] x 100) and mean intensity (total number of parasite/number of infected host) were calculated according to Bush et al. (1997)
The results obtained from the parasite number were transformed in square root of $\mathrm{x}+0.5$ and Spearman's correlation was applied to dissolved oxygen, $\mathrm{pH}$, temperature, and electric conductivity. Then, data were submitted to a multiple regression analysis.

\section{RESULTS AND DISCUSSION}

There was not difference in the water characteristics from tanks and ponds. As expected, the water temperature showed lower variation in tanks than in ponds. However, in the winter, temperature decrease was observed in both systems (Fig. 1). Consequently, the variation of dissolved oxygen was lower in tanks than in ponds, due to the controlled environment. A drastic reduction in the dissolved oxygen in ponds was verified from August to December. In tanks, the values of oxygen always stayed above 3mg. $\mathrm{l}^{-1}$ (Fig. 2). Except for February, electric conductivity in water from tanks was higher than in ponds during the experimental period. This occurred by the fact that in the first months, salt was added in tanks for parasite control. On the other hand, in March and April, no differences in the conductivity values from the both systems were observed. These small variations in aquatic characteristics are considered normal for Sipauba-Tavares (1994).

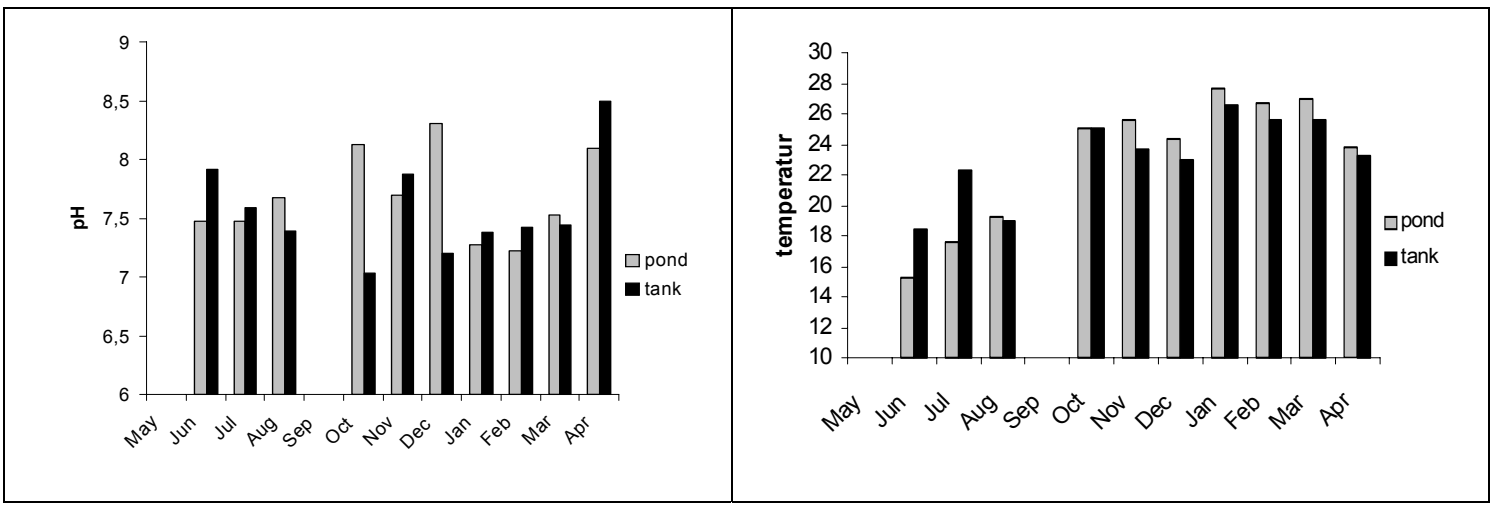

Figure 1. Mean values of water $\mathrm{pH}$ and water temperature $\left({ }^{\circ} \mathrm{C}\right)$ of tanks and ponds.

In relation to fish length and parasitism, no significant differences $(\mathrm{P}>0.05)$ were reported along the period (Table 1). In fact, significant differences on prevalence and mean intensity of parasites were registered in fish maintained in ponds. In December, fish stocked in tanks showed the largest prevalence $(100 \%)$ and mean intensity (2.9) of I. multifiliis (Table 2). Fish maintained in ponds presented the largest parasitic infestation in February, with $100 \%$ of prevalence and 3.2 parasites per fish. There was no I. multifiliis in December in fish stocked in ponds; the same absence was registered in July and November for fish kept in tanks. A 
significant negative correlation between $I$. multifiliis and electric conductivity was registered, due to concentration of dissolved salt in water. In agreement with Roberts (1981), one of the salt effects in fish is production of mucus that contains lysozyme and immunoglobulin. Singhal et al. (1986) have reported positive correlation between $\mathrm{pH}$ and I. multifiliis infestation, differing from the ones observed in this work, a negative correlation $(\mathrm{P}<0.01)$ between $I$. multifiliis and $\mathrm{pH}$. The increasing of $\mathrm{pH}$ was followed by a reduced number of parasites. This practice may be attributed to handling measures as liming to disinfection and parasite control that were constantly performed. These results confirm the benefits of liming against this protozoan of great importance in aquaculture. But, it should be remembered the attention with ammonia concentration and water temperature in ponds.

Table 1. Probability values and correlation coefficient (r) between Ichthyophthirius multifiliis and Trichodina infestations and water characteristics

\begin{tabular}{cccccc}
\hline \multicolumn{7}{c}{ Ichthyophthirius } & multifiliis \\
\hline & Parasite & $\mathrm{pH}$ & $\mathrm{DO}$ & Temperature & Condutivity \\
\hline Parasite & - & $-0.31^{* *}$ & $-0.002 \mathrm{~ns}$ & $0.02 \mathrm{~ns}$ & $-0.15^{* *}$ \\
$\mathrm{pH}$ & $-0.31^{* *}$ & - & $-0.14 \mathrm{~ns}$ & $-0.27^{* *}$ & $-0.11 \mathrm{~ns}$ \\
Oxygen & $-0.002 \mathrm{~ns}$ & $-0.14 \mathrm{~ns}$ & - & $-0.12 \mathrm{~ns}$ & $-0.10 \mathrm{~ns}$ \\
Temperature & $0.02 \mathrm{~ns}$ & $-0.27^{* *}$ & $-0.12 \mathrm{~ns}$ & - & $-0.35^{* *}$ \\
Conductivity & $-0.15^{* *}$ & $-0.11 \mathrm{~ns}$ & $-0.10 \mathrm{~ns}$ & $-0.35^{* *}$ & - \\
\hline \multicolumn{7}{c}{ Trichodina $\mathrm{sp}}$. \\
\hline Parasite & - & $-0.04 \mathrm{~ns}$ & $-0.31^{* *}$ & $-0.02 \mathrm{~ns}$ & $-0.10 \mathrm{~ns}$ \\
pH & $-0.04 \mathrm{~ns}$ & - & $-0.14 \mathrm{~ns}$ & $-0.26^{* *}$ & $-0.11 \mathrm{~ns}$ \\
Oxygen & $-0.31^{* *}$ & $-0.14 \mathrm{~ns}$ & - & $-0.12 \mathrm{~ns}$ & $-0.10 \mathrm{~ns}$ \\
Temperature & $-0.02 \mathrm{~ns}$ & $-0.26^{* *}$ & $-0.12 \mathrm{~ns}$ & - & $-0.35^{* *}$ \\
Conductivity & $-0.10 \mathrm{~ns}$ & $-0.11 \mathrm{~ns}$ & $-0.10 \mathrm{~ns}$ & $-0.35^{* *}$ & - \\
\hline
\end{tabular}

DO: dissolved oxygen; $* * \mathrm{P}<0.01 ;$ ns: $\mathrm{P}>0.05$

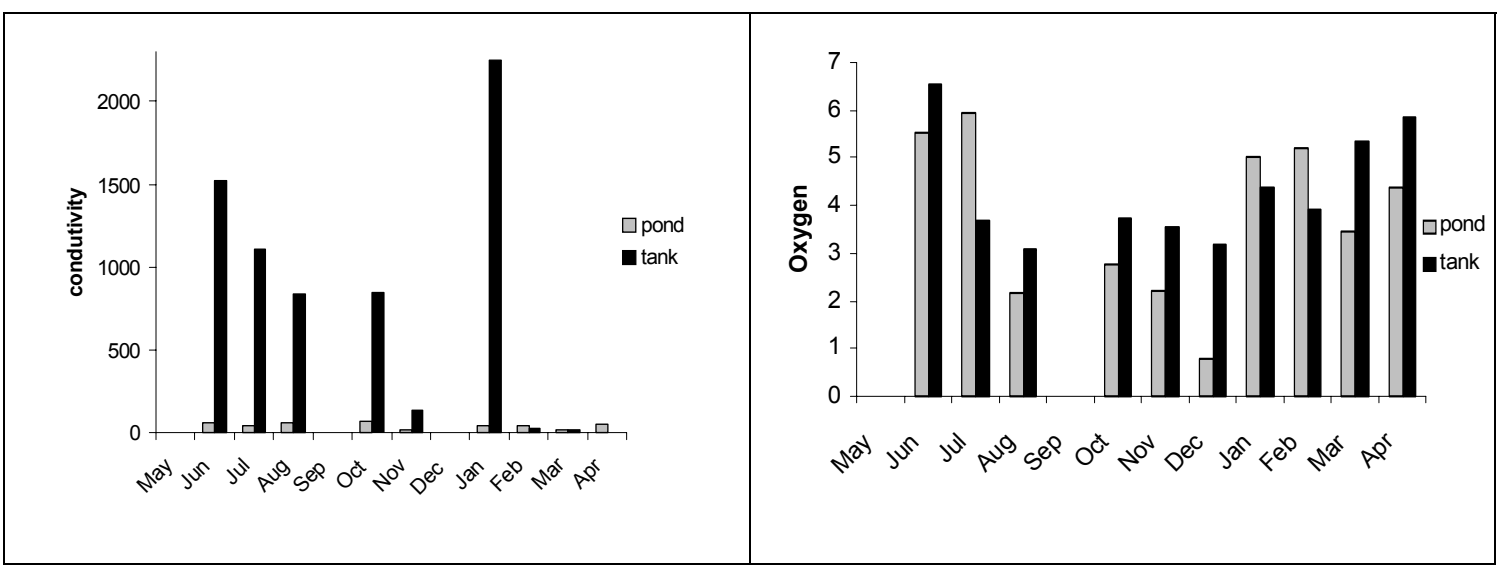

Figure 2. Mean values of electric conductivity $\left(\mu \mathrm{S} \mathrm{cm}^{-1}\right)$ and dissolved oxygen $\left(\mathrm{mg} \mathrm{l}^{-1}\right)$ in water from tanks and ponds.

The protozoan Trichodina sp. was not found in fish from ponds in March, but it showed larger prevalence rate and mean intensity in the remaining period than fish from the tanks. In fish from the ponds, $100 \%$ prevalence and 1.9 mean intensity occurred in June and July (Table 2). Consequently, in January and April, the largest prevalence (90 and $80 \%$ ) and mean intensities
(2.9 and 2.2) were respectively observed. Electric conductivity, water temperature, and $\mathrm{pH}$ did not influence the mean intensity of trichodinids, corroborating with Madsen et al. (2000). These authors did not observe influence of $\mathrm{pH}$ variation (5.45 to 6.39) in trichodinid infestations. These results differ from that reported by Singhal et al. (1986), in which 
trichodinids showed the highest number at a high water temperature and also by Halmetoja et al. (1992), in which trichodinids were influenced by cold water. Negative correlation between Trichodina sp. and dissolved oxygen was here reported. Low levels of oxygen can favour trichodinids reproduction. This is a result of organic load and increased organic matter contents, in which improve aerobic decomposition. Such as observed by Rottman at al. (1992), high levels of organic matter in water can cause stress in fish and reduce disease resistance. These results concur with Madsen et al. (2000), who reported a positive correlation between organic matter concentration and trichodinids in eels. The organic manure should be used with care since it can reduce dissolved oxygen levels and increase the parasite number.

Table 2. Values of the mean intensity (MI) and prevalence (P\%) of Ichthyophthirius multifiliis and Trichodina sp. found in Xiphophorus helleri and Xiphophorus maculatus from stocking tanks and raising ponds in a fish farm in São Paulo State, Brazil, during one year

\begin{tabular}{|c|c|c|c|c|c|c|c|c|}
\hline & \multicolumn{4}{|c|}{ Tank } & \multicolumn{4}{|c|}{ Pond } \\
\hline & \multicolumn{2}{|c|}{ I. multifiliis } & \multicolumn{2}{|c|}{ Trichodina sp. } & \multicolumn{2}{|c|}{ I. multifiliis } & \multicolumn{2}{|c|}{ Trichodina sp. } \\
\hline & MI & $\mathrm{P}$ & MI & $\mathrm{P}$ & MI & $P$ & MI & $\mathrm{P}$ \\
\hline May & $\begin{array}{c}1.6 \pm 1.03 \\
(3-0)\end{array}$ & 50 & $\begin{array}{c}1.0 \pm 0.48 \\
(1-0)\end{array}$ & 30 & $\begin{array}{c}1.7 \pm 1.25 \\
(3-0)\end{array}$ & 60 & $\begin{array}{c}1.6 \pm 0.88 \\
(2-0)\end{array}$ & 70 \\
\hline Jun & $\begin{array}{c}1.0 \pm 0.32 \\
(1-0)\end{array}$ & 10 & 0 & 0 & $\begin{array}{c}1.0 \pm 0.32 \\
(1-0)\end{array}$ & 10 & $\begin{array}{c}1.9 \pm 0.88 \\
(3-1)\end{array}$ & 100 \\
\hline Jul & 0 & 0 & $\begin{array}{c}1.0 \pm 0.48 \\
(1-0)\end{array}$ & 30 & $\begin{array}{c}1.0+0.32 \\
(1-0)\end{array}$ & 10 & $\begin{array}{c}1.9+1.20 \\
(4-1)\end{array}$ & 100 \\
\hline Aug & $\begin{array}{c}1.4+0.70 \\
(3-1)\end{array}$ & 100 & 0 & 0 & $\begin{array}{c}1.0+0.32 \\
(1-0)\end{array}$ & 10 & $\begin{array}{c}1.5 \pm 0.84 \\
(2-0)\end{array}$ & 40 \\
\hline Sep & - & - & - & - & - & - & - & - \\
\hline Oct & $\begin{array}{c}1.0 \pm 0.32 \\
(1-0)\end{array}$ & 10 & $\begin{array}{c}1.0 \pm 0.32 \\
(1-0)\end{array}$ & 10 & $\begin{array}{c}1.0 \pm 0.48 \\
(1-0)\end{array}$ & 30 & $\begin{array}{c}1.5 \pm 1.14 \\
(4-0)\end{array}$ & 80 \\
\hline Nov & 0 & 0 & $\begin{array}{c}1.0 \pm 0.32 \\
(1-0)\end{array}$ & 10 & $\begin{array}{c}3.0 \pm 0.95 \\
(3-0)\end{array}$ & 10 & 0 & 0 \\
\hline Dec & $\begin{array}{c}2.9 \pm 0.99 \\
(4-1)\end{array}$ & 100 & 0 & 0 & 0 & 0 & $\begin{array}{c}1.5 \pm 0.67 \\
(2-0)\end{array}$ & 20 \\
\hline Jan & $\begin{array}{c}1.0 \pm 0.42 \\
(1-0)\end{array}$ & 20 & $\begin{array}{c}1.0 \pm 0.32 \\
(1-0)\end{array}$ & 10 & $\begin{array}{c}1.0 \pm 0.32 \\
(1-0)\end{array}$ & 10 & $\begin{array}{c}2.9 \pm 1.51 \\
(4-0)\end{array}$ & 90 \\
\hline Feb & $\begin{array}{c}1.2 \pm 0.70 \\
(2-0)\end{array}$ & 50 & 0 & 0 & $\begin{array}{c}3.2 \pm 0.92 \\
(4-2)\end{array}$ & 100 & $\begin{array}{c}1.6 \pm 0.99 \\
(3-1)\end{array}$ & 70 \\
\hline Mar & $\begin{array}{c}1.0+0.32 \\
(1-0)\end{array}$ & 10 & $\begin{array}{c}2.0+1.51 \\
(4-0)\end{array}$ & 70 & $\begin{array}{c}4.0+1.26 \\
(4-0)\end{array}$ & 10 & 0 & 0 \\
\hline Apr & $\begin{array}{c}2.3 \pm 1.58 \\
(4-0)\end{array}$ & 60 & 0 & 0 & $\begin{array}{c}1.5 \pm 0.67 \\
(2-0)\end{array}$ & 20 & $\begin{array}{c}2.2+1.55 \\
(4-1)\end{array}$ & 80 \\
\hline Total & 1.1 & 34.2 & 0.6 & 13.3 & 1.5 & 22.5 & 1.4 & 54.2 \\
\hline
\end{tabular}

The relation between I. multifiliis and Trichodina here found confirmed the observations of Giorgiadis et al. (2001). These authors attribute the good water quality by improving the fish health. When applied multiple regression between parasites number and water parameters, the first equation concerns to I. multifiliis and the second equation to Trichodina sp. as follows: Y $=0,39-0,042886 \mathrm{DO}-0,015881 \mathrm{~T}-0,000070$ Co (1); Y $=2,24-0,21178 \mathrm{pH}+0,115680 \mathrm{DO}-$ 0,000262 Co, being Y: parasite number; DO: dissolved oxygen; $\mathrm{T}$ : water temperature; Co: water conductivity.

It can be added that physiological stress as well as the physical offences contribute as primary factor for disease occurrence and fish mortality (Rottman et al. 1992). Stress is related with lower water quality (lower values of dissolved oxygen, inadequate values of temperature, $\mathrm{pH}$, and high levels of organic matter in the water), with injuries during the fish handling (damage of mucus and scales), which facilitate the entrance 
and installation of pathogenic agents, mainly the body surface parasites like protozoa.

The use of natural control to prevent the spread of parasites in fish culture may avoid the chemical applications (Barker and Cone, 2000; Martins et al., 2007). The natural control in aquaculture is not widespread, but certainly has a promise for the future. According to Barker and Cone (2000), the keys to any successful natural control lie on better understanding of the environmental influence on parasite transmission.

Garcia et al. (2003) evaluated the infection by monogenean parasite Urocleidoides sp. in Xiphophorus sp. and concluded this infection is correlated with aquatic parameters and may be inhibited by the increase in the water electric conductivity caused by addition of sodium chloride.

The results of the present study suggest that high $\mathrm{pH}$ rates should impair the infestation by $I$. multifiliis. Thus, manipulation of $\mathrm{pH}$ by liming within holding tanks may prove to be a feasible method of controlling the skin parasites in aquaculture. However, the sensitivity of the host to $\mathrm{pH}$ changes must be considered. Salt application in the water to increase the electric conductivity may also prove to be a feasible method of I. multifiliis control in the ornamental industry. On the other hand, the dissolved oxygen reduction in the water, associated to the addition of organic fertilizer, favours the reproduction of Trichodina sp. Therefore, that practice should be carefully accomplished.

\section{ACKNOWLEDGMENTS}

The authors thank "Brejo Grande" ornamental fish farm for supplying the fish and for sampling assistance in the field and Prof. Dr. Euclides Braga Malheiros (Departamento de Ciências Exatas - FCAV, Universidade do Estado de São Paulo, Jaboticabal, SP) for statistical analysis.

\section{REFERENCES}

BARKER, D.E.; CONE, D.K. Occurrence of Ergasilus celestis (Copepoda) and Pseudodactylogyrus anguillae (Monogenea) among wild eels (Anguilla rostrata) in relation to stream flow, $\mathrm{pH}$ and temperature and recommendations for controlling their transmission among captive eels. Aquaculture, v.187, p.261-274, 2000.

BUCHMANN, K.; BJERREGAARD, J. Mebendazole treatment of pseudodactylogyrosis in an intensive eel-culture system. Aquaculture, v.86, p.139-153, 1990.

BUCHMANN, K.; MELLERGAARD, S.; KOIE, M. Pseudodactylogyrus infections in eel: a review. Dis. Aquat. Org., v.3, p.51-57, 1987.

BUCHMANN, K.S.; ROEPSTORFF, A.; WALLER, P.J. Experimental selection of mebendazole-resistent gill monogeans from the European eel, Anguilla anguilla. J. Fish Dis., v.15, p.393-400, 1992.

BUSH, A.O., LAFFERTY, K.D.; LOTZ, J.M et al. Parasitology meets ecology on its own terms. Margolis et al. Revisited. J. Parasitol., v.83, p.575-583, 1997.

CLAYTON, G.M.; PRICE, D.J. Standardization of infection and response to white spot, Ichthyophthirius multifiliis, in fish. J. Fish Biol., v.31, p.241-242, 1987.

CLAYTON, G.M.; PRICE, D.J. Interspecific and intraspecific variation in resistance to ichthyophthiriasis among poeciliid and goodeid fishes. J. Fish Biol., v.40, p.443-445, 1992.

CLAYTON, G.M.; PRICE, D.J. Heterosis in resistance to Ichthyophthirius multifiliis infections in poeciliid fish. J. Fish Biol., v.44, p.59-66, 1994.

EIRAS, J.C.; TAKEMOTO, R.M.; PAVANELLI, G.C. Métodos de estudo e técnicas laboratoriais em parasitologia de peixes. Maringá: Editora UEM, 2000. 71p.

EVANS, B.B.; LESTER, R.J.G. Parasites of ornamental fish imported to Australia. Bull. Eur. Assoc. Fish Pathol., v.21, p.51-55, 2001.

FERNANDEZ, A.J. Las enfermedades de los peces de acuario: como diagnosticarlas y curarlas. Barcelona: Editorial de Vecchi, 1981. p.115-118.

GARCIA, F.; FUJIMOTO, R.Y.; MARTINS, M.L. et al. Parasitismo de Xiphophorus sp. por Urocleidoides sp. e sua relação com os parâmetros hídricos. Bol. Inst. Pesca, v.29, p.123-131, 2003. 
GIORGIADIS, M.P.; GARDNER, I.A.; HEDRICK, R.P. The role of epidemiology in the prevention, diagnosis and control of infectious diseases in fish. Prev. Vet. Med., v.1, p.287-302, 2001.

HALMETOJA, A.; VALTONEN, E.T.; TASKINEN, J. Trichodinids (Protozoa) on fish from central finish lakes of differing water quality. Aqua Fenica, v.22, p.59-70, 1992.

HOGANS, W.E. Mortality of cultured Atlantic salmon, Salmo salar L., parr caused by an infection of Ergasilus labracis Copepoda: Poecilostomatoidea in the lower Saint John River, New Brunswick, Canada. J. Fish Dis., v.12, p.529-531, 1989.

LIMA, A.O.; BERNARDINO, G.; PROENÇA, C.E.M. Agronegócio de peixes ornamentais no Brasil e no mundo. Panor. Aquic., v.11, p.14-24, 2001.

LING, K.H.; LAM, T.J.; SIN, Y.M. Microscopic studies of Ichthyophthirius multifiliis infection in ornamental fish. Singapore J. Prim. Ind., v.23, p.9-14, 1995.

LING, K.H.; SIN, Y.M.; LAM, T.J. Studies on immune response in freshwater ornamental fish against Ichthyophthirius multifiliis Fouquet 1876. Singapore J. Prim. Ind., v.20, p.46-52, 1992.

MADSEN, H.C.K.; BUCHMANN, K.; MELLERGAARD, S. Association between trichodiniasis in eel (Anguilla anguilla) and water quality in recirculation systems. Aquaculture, v.187, p.275-281, 2000.

MARTINS, M.L.; GARCIA, F.; PIAZZA, R.S. et al. Camallanus maculatus n. sp. (Nematoda: Camallanidae) in an ornamental fish Xiphophorus maculatus (Osteichthyes: Poeciliidae) cultivated in São Paulo State, Brazil. Arq. Bras. Med. Vet. Zootec., v.59, p.1224-1230, 2007.

MARTINS, M.L.; GHIRALDELLI, L.; GARCIA, F. et al. Experimental infection in Notodiaptomus sp. (Crustacea: Calanoida) with larvae of Camallanus sp. (Nematoda: Camallanidae). Arq. Bras. Med. Vet. Zootec., v.59, p.382-386, 2007.
MARTINS, M.L.; ONAKA, E.M.; MORAES, F.R. et al. Recent studies on parastic infections of freshwater cultivated fish in the state of São Paulo, Brazil. Acta Sci., v.24, p.981-985, 2002.

PRICE, D.J.; BONE, L.M.; MANNING, M.J. et al. Maternal effects and resistance to infection by Ichthyophthirius multifiliis in Xiphophorus maculatus. Fish Immunol., v.1, p.233-244, 1985.

RANZANI-PAIVA, M.J.T.; FELIZARDO, N.N.; EIRAS A.C. et al. Análise parasitológica de brânquias e pele de Tilápia-do-nilo Oreochromis niloticus Linnaeus, 1757 criados em tanque-rede na represa Guarapiranga, SP. In: ENCONTRO BRASILEIRO DE PATOLOGISTAS DE ORGANISMOS AQUÁTICOS, 5., 1998, Maringá. Anais... Maringá, 1998. p.140.

ROBERTS, R.J. Patologia de los peces. Madri: Mundi-Prensa, 1981, 367p.

ROTTMAN, R.W.; FRANCIS-FLOYD, R.; DURBOROW $\mathrm{R}$. The role of stress in fish disease. Stoneville, MS: Southerm Regional Aquaculture Center Publication, 1992. 474p.

SINGHAL, R.N.; JEET S.; DAVIES, R.W. The relationships between changes in selected physico-chemical properties of water and the occurrence of fish parasites in Haryana, India. Trop. Ecol., v.27, p.1-9, 1986.

SIPAÚBA-TAVARES, L.H. Limnologia aplicada à aquicultura. Jaboticabal: Funesp, 1994. 70p. (Boletim Técnico, 1)

TAVARES-DIAS, M.; MARTINS, M.L.; MORAES F.R. Fauna parasitária de peixes oriundos de "pesque-pague" do município de Franca, São Paulo, Brasil. I. Protozoários. Rev. Bras. Zool., v.18, p.67-79, 2001.

VARGAS, L.; POVH, J.A.; RIBEIRO, R.P. et al. Prevalência de ectoparasitas en tilapias del Nilo (Oreochromis niloticus) de origem tailandesa. Arq. Cienc. Vet. Zool., v.3, p.32-37, 2000.

WOOTEN, R. Control of parasitic diseases of cultured fish: recent and future trends. Parasitol. Int., v.47, p.71-95, 1998. 